\title{
Tomato Brown Rugose Fruit Virus (ToBRFV): A Potential Threat for Tomato Production in Florida ${ }^{1}$
}

\author{
Ozgur Batuman, Salih Yilmaz, Pamela Roberts, Eugene McAvoy, Samuel Hutton, Kishore Dey, \\ and Scott Adkins ${ }^{2}$
}

\section{Introduction}

Tobamoviruses are mechanically transmitted plant viruses that cause severe economic damage to vegetable and ornamental crops in Florida and worldwide. Tomato mosaic virus (ToMV) and tobacco mosaic virus (TMV) are the most commonly occurring tobamoviruses infecting tomato plants (Solanum lycopersicum) in Florida (Adams et al. 2009; Baker and Adkins 2000). Tomato cultivars with resistance to these tobamoviruses are commercially available and were developed by introgression of resistance genes from wild plants into cultivated crops (Lanfermeijer et al. 2005).

Tomato cultivars harboring the $\mathrm{Tm}-2^{2}$ resistance gene are resistant to ToMV, TMV, and other tobamoviruses (Hall 1980; de Ronde et al. 2014). However, the Tm- $2^{2}$ resistance gene in tomato cultivars does not provide resistance against tomato brown rugose fruit virus (ToBRFV), a recently described tobamovirus first detected in the Middle East (Salem et al. 2016; Luria et al. 2017). ToBRFV also infects pepper and eggplant (Luria et al. 2017; EPPO 2019; Salem et al. 2020).

ToBRFV was initially detected in Jordan and Israel in 2014 and 2015, respectively, and currently it has been detected in tomato production areas worldwide. The emergence and spread of ToBRFV in tomato production areas, including California, Mexico, Jordan, Israel, Turkey, Italy, Germany, Greece, and China, has accelerated, representing a major economic concern (Cambrón-Crisantos et al. 2018; Fidan et al. 2019; Panno et al. 2019; Ling et al. 2019; Menzel et al. 2019; Yan et al. 2019; Beris et al. 2020)

\section{No commercial tomato cultivars are known to be} resistant to ToBRFV, even those previously resistant to other tobamoviruses. ToBRFV overcomes (breaks) the $T m-2^{2}$ and all other resistance genes currently used to protect tomatoes against tobamoviruses. Although these genes are not routinely used in Florida field-grown tomato cultivars, it is currently unknown how ToBRFV may affect tomato production in Florida. Thus far, because of extensive crop handling and manipulation, ToBRFV has primarily been a threat to tomato production in protected culture (greenhouses, screenhouses, and high tunnels), though outbreaks in open fields have been reported. In September 2019, ToBRFV was detected in fresh tomato fruits imported from Canada and Mexico for sale in Florida grocery stores (Batuman and Dey, unpublished results). Since this first detection, ToBRFV has been found in tomato, pepper, and

1. This document is PP360, one of a series of the Plant Pathology Department, UF/IFAS Extension. Original publication date December 2020. Visit the EDIS website at https://edis.ifas.ufl.edu for the currently supported version of this publication.

2. Ozgur Batuman, assistant professor; Salih Yilmaz, graduate student; Pamela Roberts, professor, Plant Pathology Department; Eugene McAvoy, regional vegetable Extension agent emeritus and associate director for stakeholder relations, UF/IFAS Southwest Florida Research and Education Center; Samuel Hutton, associate professor, Horticultural Sciences Department, UF/IFAS Gulf Coast REC; Kishore Dey, Bureau of Entomology, Nematology and Plant Pathology, Florida Department of Agriculture and Consumer Services; and Scott Adkins, research plant pathologist (virologist), USDA-ARS; UF/ IFAS Extension, Gainesville, FL 32611.

The Institute of Food and Agricultural Sciences (IFAS) is an Equal Opportunity Institution authorized to provide research, educational information and other services

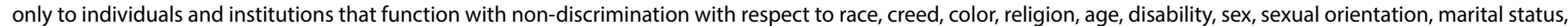

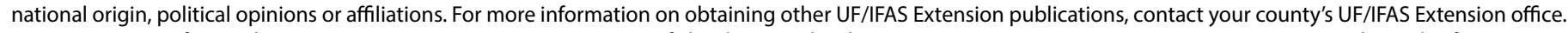
U.S. Department of Agriculture, UF/IFAS Extension Service, University of Florida, IFAS, Florida A \& M University Cooperative Extension Program, and Boards of County Commissioners Cooperating. Nick T. Place, dean for UF/IFAS Extension. 
eggplant plants grown in noncommercial sites like community gardens in several locations in Florida.

\section{ToBRFV Characteristics}

As a tobamovirus, ToBRFV shares several properties and disease symptoms with the more familiar members of this group that occur in Florida, including ToMV, TMV, and tomato mottle mosaic virus (ToMMV) (Li et al. 2013; Nagai et al. 2019; Webster et al. 2014).

\section{Symptoms}

It is impossible to identify a tobamovirus based upon symptoms alone due to the similarity of symptoms induced by all tobamoviruses. In addition, symptoms vary depending on the species and strain of the virus, growth stage of the plant when infected, and the tomato cultivar.

Generally, plants infected with a tobamovirus are stunted, and leaves show mosaic or mottling (green and yellow areas) and distortion (Figure 1A-E). In severe cases, leaf symptoms include elongation or "shoestring"-like growth (Figure 1A). Maturing fruits show a range of symptoms, including no symptoms, some degree of deformation and chlorotic spots (i.e., uneven ripening or "marbling"), and brown wall and necrotic lesions (Figure 2).
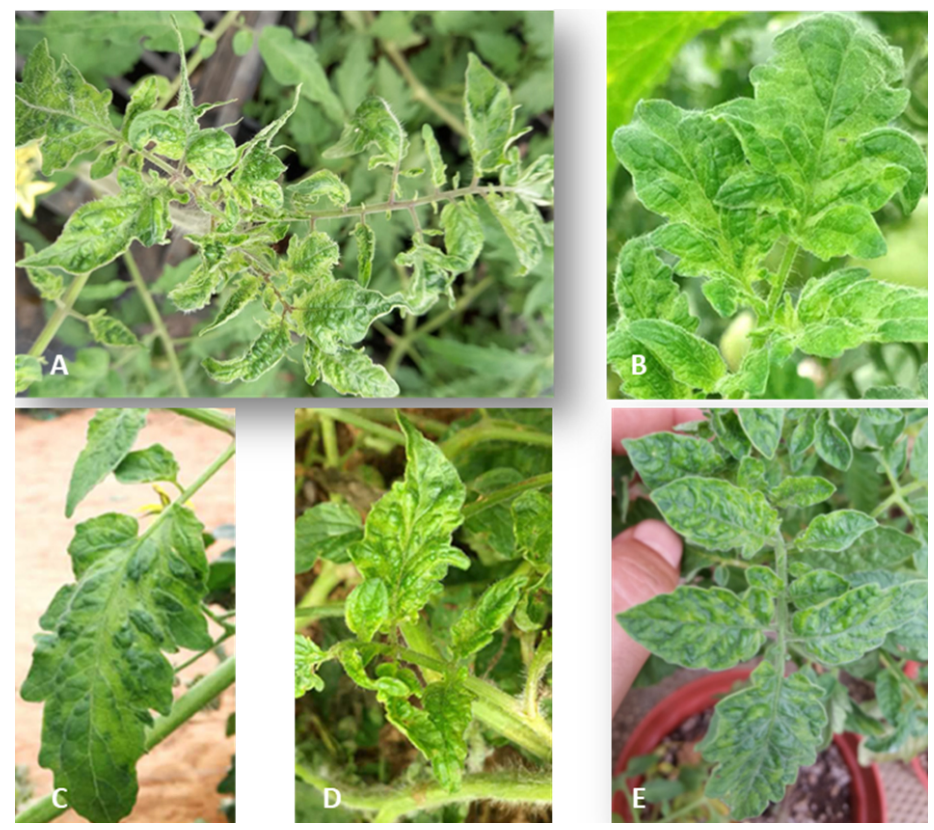

Figure 1. Foliar symptoms of tobamoviruses. (A) Distortion and "shoestring" leaf symptoms in a tomato plant infected with tobamovirus. (B-E) Symptoms of mosaic and mottle in leaves of tomato plants infected with tomato brown rugose fruit virus (ToBRFV). Credits: A. Dombrovsky; Fidan et al. (2019) and Luria et al. (2017)
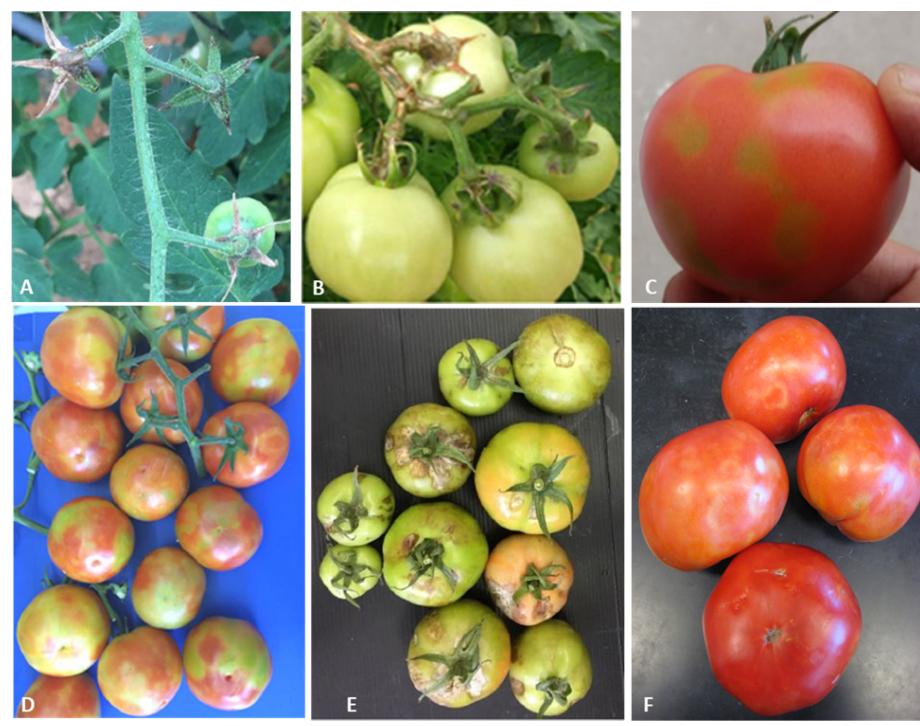

Figure 2. Fruit symptoms of tomato brown rugose fruit virus (ToBRFV). (A) Dried pedicles and calyces on cherry tomato plants leading to fruit abscission. (B) Necrotic symptoms on pedicle and calyces. (C-D) Typical fruit symptoms with yellow/green "marbling" spots. (E) Cracked, scarred and discolored fruits from tomato plants with mixed infections of ToBRFV and pepino mosaic virus (PepMV). (F) Fruit symptoms with yellow/green "marbling" spots from Florida grocery stores.

Credits: A. Dombrovsky, O. Batuman, Fidan et al. (2019) and Luria et al. (2017)

\section{How ToBRFV Is Different from Other Tobamoviruses}

The main difference between ToBRFV and other tobamoviruses is that ToBRFV breaks the $T m-2^{2}$ resistance gene and induces more severe fruit symptoms, which in some cases include brown wrinkled (rugose) patches, especially when present in mixed infections with other tomato-infecting viruses (Figure 1E). Brown (necrotic) streaks may develop on stems, petioles, and calices (Figure $\mathbf{2 A}$ and B). ToBRFV can be found in mixed infections with pepino mosaic virus (PepMV), a virus used for cross-protection in tomatoes produced in Canada and Europe. For instance, both viruses were identified in some of the Florida tomato fruits coming from Mexico and Canada.

\section{Survival and Transmission}

Tobamoviruses, including ToBRFV, are robust and can survive in plant debris $>10$ years. Survival in soil and on contaminated objects or on surfaces (benches, trellising ropes, plastic containers and equipment) used in any stage of production can range from months to years.

\section{Tobamoviruses, including ToBRFV, are efficiently} transmitted by contact, particularly in protected culture, where plants are frequently handled. Although most Florida field-tomato varieties are determinate and are 
tied several times throughout the season, they are not intensively handled (i.e., pruning and tying) by workers throughout the production cycle. There is no insect vector. However, bumble bees were shown to carry the virus in greenhouses (Levitzky et al. 2019). Thus, tobamoviruses may be less likely to spread extensively in open-field production systems. Tobamoviruses readily contaminate the seed coat and can be spread long distance with seed, but the viruses are not believed to infect the embryo.

\section{What to Do If You Think You Have ToBRFV in Your Field}

Commercially available immunostrip ("dipstick") tests for TMV also detect ToBRFV and other tobamoviruses, including ToMV and ToMMV. If you see tobamovirus-like symptoms in your tomato plants, use an immunostrip test for TMV (Figure 3). If your tomato has virus-like symptoms and your test is positive by this assay, additional molecular tests (i.e., RT-PCR) are required for ToBRFV confirmation. If growers see unusual symptoms or suspect they may have a virus, they should immediately contact their local Extension office for assistance or submit samples to their local UF/IFAS Plant Diagnostic Lab or FDACS-DPI (FDACS-DPI Helpline Number 352-395-4600).

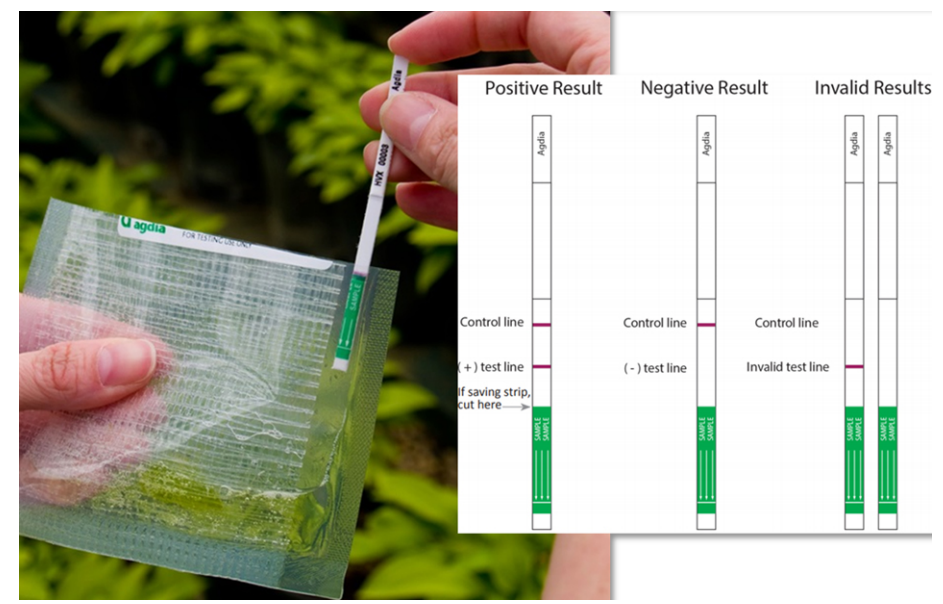

Figure 3. Growers can detect tobamoviruses with commercially available TMV immunostrip "dipstick" tests in 5-20 min in the field. Credits: Agdia@

\section{The Florida Response}

ToBRFV has rapidly spread across the globe in only a few years. It is highly virulent and is not controlled by currently available resistance genes. Although ToBRFV is not currently established in Florida, it was detected in imported tomato fruits sold in national chain grocery stores in Naples and Gainesville, Florida in fall 2019, as well as in a few community gardens. Therefore, we should take the following precautions to avoid introduction of ToBRFV to tomato production fields:

1. Seed companies, as a standard practice, currently test for the presence of tobamoviruses. Contact the seed company representatives you work with to ensure your seed was tested for tobamoviruses. Purchase only seeds certified to be ToBRFV-free.

2. Inspect and discard tomato transplants with virus symptoms before planting in your field.

3. Train your workers about ToBRFV (and potential occurrence in tomatoes sold in grocery stores) and implement sanitation measures such as washing hands and clothes before work, avoiding bringing or touching tobacco and other potential host plant materials, and disinfecting common tools, benches, and other equipment. Although undamaged fruit surfaces do not have viable virus particles, juice and other edible parts are highly infectious (Klap et al. 2020). Do not touch or bring tomato (or pepper) fruits from the outside into your production facilities.

4. Monitor for virus symptoms to allow early detection if introduced into fields.

If you have additional questions or need assistance in testing, contact your local UF/IFAS Extension agent or Ozgur Batuman at UF/IFAS Southwest Florida REC (email: obatuman@ufl.edu).

\section{Summary}

- ToBRFV is a recently described tobamovirus that impacts solanaceous crops such as tomato, pepper, and eggplant.

- ToBRFV is not currently established in Florida, but its presence in grocery store tomato fruits and community gardens requires proactive preventative measures.

- What we know about this virus to date suggests that ToBRFV is primarily a threat to tomato production in protected culture (greenhouses and screenhouses). However, a few outbreaks in open fields in Mexico and Israel have occurred.

- Genetic resistance is not currently available because ToBRFV overcomes (breaks) all known resistance genes in tomato cultivars.

- ToBRFV is spread quickly and efficiently by contact with any infected plant material. Although it is not known to infect seed (embryo), it can readily contaminate 
the seed coat (outside of seed) and can be spread long distance with seed (and fruit).

- ToBRFV particles are very robust and can survive for $>\mathbf{1 0}$ years in soil and infected debris or on contaminated equipment and implements.

- Symptoms include mosaic and mottling, irregular ripening, and necrosis and are similar to those of other tobamoviruses.

- If ToBRFV is suspected, TMV immunostrips can detect it, but confirmation will require further laboratory testing.

- Once the virus is introduced in an area, control measures are very limited and mainly rely on elimination of infected plants and following strict sanitation measures, such as regular worker handwashing, changing clothes, and cleaning boots before entering production areas.

\section{Literature Cited}

Adams, M. J., J. F. Antoniw, and J. Kreuze. 2009. "Virgaviridae: A New Family of Rod-Shaped Plant Viruses." Arch Virol. 154 (12): 1967-72.

Baker, C., and S. Adkins. 2000. "Peppers, Tomatoes and Tobamoviruses." Plant Pathology Circular No. 400. Gainesville: Florida Department of Agriculture \& Consumer Services, Division of Plant Industry.

Beris, D., I. Malandraki, O. Kektsidou, I. Theologidis, N. Vassilakos, and C. Varveri. 2020. "First Report of Tomato Brown Rugose Fruit Virus Infecting Tomato in Greece." Plant Disease 104 (7): 2035.

Cambrón-Crisantos, J. M., J. Rodríguez-Mendoza, J. B. Valencia-Luna, S. A. Rangel, C. De Jesús García-Ávila, and J. A. López-Buenfil. 2018. "First Report of Tomato Brown Rugose Fruit Virus (ToBRFV) in Michoacan, Mexico." Mexican Journal of Phytopathology 37:185-92.

de Ronde, D., P. Butterbach, and R. Kormelink. 2014. "Dominant Resistance against Plant Viruses." Frontiers in Plant Science 5:307.

EPPO Global Database. 2020. “Tomato Brown Rugose Fruit Virus (ToBRFV).” https://gd.eppo.int/taxon/TOBRFV

Fidan, H., P. Sarikaya, and O. Calis. 2019. "First Report of Tomato Brown Rugose Fruit Virus on Tomato in Turkey." New Disease Reports 39:18.
Hall, T. J. 1980. "Resistance at the Tm-2 Locus in the Tomato to Tomato Mosaic Virus." Euphytica 29 (1): 189-197.

Klap, C., N. Luria, E. Smith, E. Bakelman, E. Belausov, O. Laskar, O. Lachman, A. Gal-O, and A. Dombrovsky. 2020. "The Potential Risk of Plant-Virus Disease Initiation by Infected Tomatoes." Plants 9 (5): 623. https://doi. org/10.3390/plants9050623

Lanfermeijer, F. C., J. Warmink, and J. Hille. 2005. “The Products of the Broken Tm-2 and the Durable Tm-2 ${ }^{2}$ Resistance Genes from Tomato Differ in Four Amino Acids." Journal of Experimental Botany 56:2925-33.

Levitzky, N., E. Smith, O. Lachman, N. Luria, Y. Mizrahi, H. Bakelman, et al. 2019. “The Bumblebee Bombus terrestris Carries a Primary Inoculum of Tomato Brown Rugose Fruit Virus Contributing to Disease Spread in Tomatoes." PLoS ONE 14 (1): e0210871. https://journals.plos.org/plosone/ article?id=10.1371/journal.pone.0210871

Li, R., S. Gao, Z. Fei, and K.-S. Ling. 2013. “Complete Genome Sequence of a New Tobamovirus Naturally Infecting Tomatoes in Mexico." Genome Announcements 1:e00794-13.

Ling, K.-S., T. Tian, S. Gurung, R. Salati, and A. Gilliard. 2019. "First Report of Tomato Brown Rugose Fruit Virus Infecting Greenhouse Tomato in the US." Plant Disease 103:1439.

Luria, N., E. Smith, V. Reingold, I. Bekelman, M. Lapidot, I. Levin, N. Elad, Y. Tam, N. Sela, A. Abu-Ras, N. Ezra et al. 2017. "A New Israeli Tobamovirus Isolate Infects Tomato Plants Harboring Tm-2 $2^{2}$ Resistance Genes." PLOS ONE 12:e0170429.

Menzel, W., D. Knierim, S. Winter, J. Hamacher, and M. Heupel. 2019. "First Report of Tomato Brown Rugose Fruit Virus Infecting Tomato in Germany." New Disease Reports 39:2044.

Nagai, A., L. M. Duarte, A. L. Chaves, L. E. Peres, and D. Y. Dos Santos. 2019. “Tomato Mottle Mosaic Virus in Brazil and Its Relationship with Tm-2 ${ }^{2}$ Gene." European Journal of Plant Pathology 155:353-359.

Panno, S., A. Caruso, and S. Davino. 2019. "First Report of Tomato Brown Rugose Fruit Virus on Tomato Crops in Italy." Plant Disease 103:1443. 
Salem, N. M., M. J. Cao, S. Odeh, M. Turina, and R. Tahzima. 2020. "First Report of Tobacco Mild Green Mosaic Virus and Tomato Brown Rugose Fruit Virus Infecting Capsicum annuum in Jordan." Plant Disease 104 (2): 601.

Salem, N., A. Mansour, M. Ciuffo, B. Falk, and M. Turina. 2016. "A New Tobamovirus Infecting Tomato Crops in Jordan." Archives of Virology 161:503-6.

Webster, C. G., E. N. Rosskopf, L. Lucas, H. C. Mellinger, and S. Adkins. 2014. "First Report of Tomato Mottle Mosaic Virus Infecting Tomato in the United States." Plant Health Progress 15 (4): 151-2.

Yan, Z. Y., H. Y. Ma, S. L. Han, C. Geng, Y. P. Tian, and X. D. Li. 2019. "First Report of Tomato Brown Rugose Fruit Virus Infecting Tomato in China." Plant Disease 103 (11): 2973. 